\title{
Uncertainty Reporting for Experimental Thermodynamic Properties ${ }^{\dagger}$ (Supporting Information)
}

\author{
Qian Dong,* Robert D. Chirico, Xinjian Yan,** \\ Xiangrong Hong, and Michael Frenkel
}

Thermodynamics Research Center (TRC)

Physical and Chemical Properties Division

National Institute of Standards and Technology (NIST)

Boulder, Colorado 80305-3328

$\dagger$ This contribution of the National Institute of Standards and Technology is not subject to copyright in the United States.

* To whom correspondence should be addressed. Email: qdong@ boulder.nist.gov.

** Present address: Scientific Information Center, 564 E $130^{\text {th }}$ Way, Thornton, CO 80241 


\section{Supporting Information}

The following articles were used in compilation of the statistics reported in this paper.

1. Deschner, W. W.; Brown, G. G. P-V-T Relations for Propane. Ind. Eng. Chem. 1940, 32, 836-840.

2. Kay, W. B. Liquid-Vapor Equilibrium Relations in Binary Systems. The Ethane - n-Butane System. Ind. Eng. Chem. 1940, 32, 353-357.

3. Mason, S. G.; Naldrett, S. N.; Maass, O. A Study of the Coexistence of the Liquid and Gaseous States of Aggregation in the Critical-temperature Region. Ethane. Can. J. Res. Sect. B, 1940, 18, 103-117.

4. Lu, H.; Newitt, D. M.; Ruhemann, M. Two-phase Equilibrium in Binary and Ternary Systems IV. The System Ethane-Propylene. Proc. R. Soc. London A, 1941, 178, 506-525.

5. Hojendahl, K. Dielectric Constant, Viscosity, Surface Tension, and Critical Data of Boron Tribromide, Dioxane, and Ethylene Dichloride. Mat.-Fys. Medd. - K. Dan. Vidensk. Selsk. 1946, 24, 3-11.

6. Griffin, D. N. The Critical Point of Nitromethane. J. Am. Chem. Soc. 1949, 71, 1423-1426.

7. Atack, D.; Schneider, W. G. Solubility Measurements in the Critical Temperature Region. I. J. Phys. Chem. 1950, 54, 1323-1336.

8. Atack, D.; Schneider, W. G. The Coexistence Curve of Sulfur Hexafluoride in the Critical Region. J. Phys. Colloid Chem. 1951, 55, 532-539.

9. Beattie, J. A.; Douslin, D. R.; Levine, S. W. The Vapor Pressure and Critical Constants of Neopentane. J. Chem. Phys. 1951, 19, 948.

10. Kay, W. B.; Warzel, F. M. 2,2,4-Trimethylpentane (Isooctane), Vapor Pressure, Critical Constants and Saturated Vapor and Liquid Densities. Ind. Eng. Chem. 1951, 43, 1150-1152.

11. Bloomer, O. T.; Parent, J. D. Physical-Chemical Properties of Methane + Nitrogen Mixtures. Inst. Gas Technol. Chicago, Res. Bull. 17, 1952, 1-35.

12. Kay, W. B.; Nevens, T. D. Liquid-Vapor Equilibrium Relations in Binary System. Chem. Eng. Prog. Symp. Ser. 1952, 48, 108-114.

13. Murray, F. E.; Mason, S. G. Coexistence Phenomena in the Critical Region. I. The Gravity Effect in Ethane from Light Scattering. Can. J. Chem. 1952, 30, 550-561.

14. Kay, W. B.; Brice, D. B. Liquid-Vapor Equilibrium Relations in Ethane-Hydrogen Sulfide System. Ind. Eng. Chem. 1953, 45, 615-618.

15. Kay, W. B.; Rambosek, G. M. Liquid-Vapor Equilibrium Relations in Binary Systems. Propane-Hydrogen Sulfide Systems. Ind. Eng. Chem. 1953, 45, 221-226.

16. Whiteway, S. G.; Mason, S. G. Coexistence Phenomena in the Critical Region II. Influence of Gravity on the Coexistence Curves of Ethane, Ethylene, and Xenon. Can. J. Chem. 1953, 31, 569-584.

17. Palmer, H. B. Schlieren Studies in the Critical Region. J. Chem. Phys. 1954, 22, 625-634.

18. Clegg, H. P.; Rowlinson, J. S. Physical Properties of Some Fluorine Compounds and Their Solutions II. Part 2. The System Sulfur Hexafluoride + Propane. Trans. Faraday Soc. 1955, 51, 1333-1340.

19. Kobe, K. A.; Crawford, H. R.; Stephenson, R. W. Critical Properties and Vapor Pressures of Some Ketones. Ind. Eng. Chem. 1955, 47, 1767-1772.

20. Mears, W. H.; Stahl, R. F.; Orfeo, S. R.; Shair, R. C.; Kells, L. F.; Thompson, W.; McCann, H. Thermodynamic Properties of Halogenated Ethanes and Ethylenes. Ind. Eng. Chem. 1955, 47, 1449-1454.

21. Ambrose, D. Vapor Pressures and Critical Temperature of Acetylene and Carbon Dioxide. Trans. Faraday Soc. 1956, 52, 772-781.

22. Kay, W. B.; Albert, R. E. Liquid-Vapor Equilibrium Relations in the Ethane-Cyclohexane System. Ind. Eng. Chem. 1956, 48, 422-425.

23. Ambrose, D.; Grant, D. G. The Critical Temperatures of Some Hydrocarbons and Pyridine Bases. Trans. Faraday Soc. 1957, 53, 771-778.

24. Nichols, W. B.; Reamer, H. H.; Sage, B. H. Volumetric and Phase Behavior in the Hydrogen-Hexane System. AIChE J. 1957, 3, 262-267.

25. Vohra, S. P.; Kobe, K. A. Volumetric Behaviour and Critical Constants of Isopentane. J. Chem. Eng. Data 1959, 4, 329-330.

26. Ambrose, D.; Cox, J. D.; Townsend, R. The Critical Temperatures of Forty Organic Compounds. Trans. Faraday Soc. 1960, 56, 1452-1459. 
27. Martin, J. J. Thermodynamic Properties of Dichlorotetrafluoroethane. J. Chem. Eng. Data 1960, 5, 334-336.

28. McCracken, P. G.; Storvick, T. S.; Smith, J. M. Phase Behavior from Enthalpy Measurements. Benzene-Ethyl Alcohol and n-Pentane-Ethyl Alcohol Systems. J. Chem. Eng. Data 1960, 5, 130-132.

29. Partington, E. J.; Rowlinson, J. S.; Weston, J. F. The Gas-Liquid Critical Temperatures of Binary Mixtures. Part 1. Trans. Faraday Soc. 1960, 56, 479-485.

30. Cheng, D. C. H.; McCoubrey, J. C.; Phillips, D. G. Critical Temperatures of Some Organic Cyclic Compounds. Trans. Faraday Soc. 1962, 58, 224-229.

31. Connolly, J. F. Ideality of n-Butane. J. Phys. Chem. 1962, 66, 1082-1086.

32. Connolly, J. F.; Kandalic, G. A. Saturation Properties and Liquid Compressibilities for Benzene and nOctane. J. Chem. Eng. Data 1962, 7, 137-139.

33. Vohra, S. P.; Kang, T.-L.; Kobe, K. A.; McKetta, J. J. Pressure-Volume-Temperature Properties of Propyne. J. Chem. Eng. Data 1962, 7, 150-155.

34. Ambrose, D. Critical Temperatures of Some Phenols and Other Organic Compounds. Trans. Faraday Soc. 1963, 59, 1988-1993.

35. Ambrose, D.; Townsend, R. Thermodynamic Properties of Organic Oxygen Compounds IX. The Critical Properties and Vapor Pressures above Five Atmospheres of Six Aliphatic Alcohols. J. Chem. Soc. 1963, 54, 3614-3625.

36. Brown, J. A. Physical Properties of Perfluoropropane. J. Chem. Eng. Data 1963, 8, 106-108.

37. Cheng, D. C. H. Critical Temperatures and Volumes of Some Binary Systems. Chem. Eng. Sci. 1963, 18, 715-724.

38. Jones, I. W.; Rowlinson, J. S. Gas-Liquid Critical Temperatures of Binary Mixtures. Part 2. Trans. Faraday Soc. 1963, 59, 1702-1708.

39. Hsu, C. C.; McKetta, J. J. Pressure-Volume-Temperature Properties of Methyl Chloride. J. Chem. Eng. Data 1964, 9, 45-51.

40. Kay, W. B. P-T-x Diagrams in the Critical Region. Acetone-n-Alkane Systems. J. Phys. Chem. 1964, 68, 827-831.

41. Shim, J.; Kohn, J. P. Vapor-Liquid Equilibrium Relations in Binary Systems. Ethylene-Chloroform System. J. Chem. Eng. Data 1964, 9, 1-2.

42. Skaates, J. M.; Kay, W. B. The Phase Relations of Binary Systems that Form Azeotropes. Chem. Eng. Sci. 1964, 19, 431-444.

43. Counsell, J. F.; Green, J. H. S.; Hales, J. L.; Martin, J. F. Thermodynamic Properties of Fluorine Compounds. Part 2. Physical and Thermodynamic Properties of Hexafluorobenzene. Trans. Faraday Soc. 1965, 61, 212218.

44. McMicking, J. H.; Kay, W. B. Vapor Pressures and Saturated Liquid and Vapor Densities of the Isomeric Heptanes and Isomeric Octanes. Proc. Am. Pet. Inst., Sect. 3, 1965, 45, 75-90.

45. Khodeeva, S. M. Visual Observation of Gas-Gas Mixture. Russ. J. Phys. Chem. (Engl. Transl.) 1966, 40, 1061-1063.

46. Mears, W. H.; Rosenthal. E.; Sinka, J. V. Pressure-Volume-Temperature Behavior of Pentafluoromonochlorethane. J. Chem. Eng. Data 1966, 11, 338-343.

47. Michels, A.; Wassenaar, T.; Wolkers, G. J.; Prins, Chr.; van de Klundert, L. P-V-T Data and Thermodynamical Properties of Freon-12 $\left(\mathrm{CCl}_{2} \mathrm{~F}_{2}\right)$ and Freon-13 $\left(\mathrm{CClF}_{3}\right)$ Fluorocarbons at Temperatures between $0^{\circ}$ and $150^{\circ} \mathrm{C}$ and at Pressures up to 400 Atm. J. Chem. Eng. Data 1966, 11, 449-452.

48. Ambrose, D.; Broderick, B. E.; Townsend, R. The Vapour Pressures above the Normal Boiling Point and the Critical Pressures of Some Aromatic Hydrocarbons. J. Chem. Soc. A 1967, 633-641.

49. Denisova, N. D.; Safronova, E. K.; Pustil'nik, A. I.; Bystrova, O. N. Boundary Liquid-Vapor Curve and Saturated Vapour Pressure of Zirconium and Hafnium Tetrachlorides. Russ. J. Phys. Chem. (Engl. Transl.) 1967, 41, 30-33.

50. McCain, W. D.; Ziegler, W. T. The Critical Temperature, Critical Pressure, and Vapor Pressure of Argon. J. Chem. Eng. Data 1967, 12, 199-202.

51. Nisel'son, L. A.; Sokolova, T. D.; Stolyarov, V. I. Some Properties of Hafnium Tetrachloride in the Liquid and Vapor States. Russ. J. Phys. Chem. (Engl. Transl.) 1967, 41, 884-886. 
52. Shank, R. L. Thermodynamic Property of 1,1,1,2,2-Pentafluoropropane (Refrigerant 245). J. Chem. Eng. Data 1967, 12, 474-480.

53. Tsiklis, D. S.; Prokhorov, V. M. Phase Equilibria in Systems Containing Fluorine Compounds. Zh. Fiz. Khim. 1967, 41, 2195-2199.

54. Zawisza, A. C. High Pressure Phase Equilibriums and the Compressibility of the Sulfur Dioxide - Diethyl Ether System. Bull. Acad. Pol. Sci. Ser. Sci. Chim. 1967, 15, 291-297

55. Campbell, A. N.; Chatterjee, R. M. Orthobaric Data of Certain Pure Liquids in the Neighborhood of the Critical Point. Can. J. Chem. 1968, 46, 575-581.

56. Grigor, A. F.; Steele, W. A. Physical Properties of Fluid $\mathrm{CH}_{4}$ and $\mathrm{CD}_{4}$. J. Chem. Phys. 1968, 48, 1032-1037.

57. Makarevich, L. A.; Sokolova, E. S.; Sorina, G. A. Critical Parameters of Sulfur Hexafluoride. Zh. Fiz. Khim. 1968, 42, 22-23.

58. Campbell, A. N.; Chatterjee, R. M. The Critical Constants and Orthobaric Densities of Acetone, Chloroform Benzene, and Carbon Tetrachloride. Can. J. Chem. 1969, 47, 3893-3898.

59. Kreglewski, A.; Kay, W. B. The Critical Constants of Conformal Mixtures. J. Phys. Chem. 1969, 73, 33593366.

60. Ricci, F. P.; Scafe, E. Orthobaric Density of $\mathrm{CH}_{4}$ in the Critical Region. Phys. Lett. A 1969, $29,650-651$.

61. Kobe, K. A.; Mathews, J. F. Critical Properties and Vapor Pressures of Some Organic Nitrogen and Oxygen Compounds. J. Chem. Eng. Data 1970, 15, 182-186.

62. Lin, D. C. K.; Silberberg, I. H.; McKetta, J. J. Volumetric Behavior, Vapor Pressure and Critical Properties of Cyclopropane. J. Chem. Eng. Data 1970, 15, 483-492.

63. Vennix, A. J.; Leland, T. W.; and Kobayashi, R. Low-Temperature Volumetric Properties of Methane. $J$. Chem. Eng. Data 1970, 15, 238-243.

64. Zawisza, A. C.; Glowka, S. Liquid-vapour Equilibria and Thermodynamic Functions of Dimethyl Ether Sulphur Dioxide System up to $300^{\circ} \mathrm{c}$ and 77.81 atmospheres. Bull. Acad. Pol. Sci. Ser. Sci. Chim., 1970, 18, 549-554

65. Ambrose, D.; Sprake, C. H. S. Thermodynamic Properties of Fluorine Compound. J. Chem. Soc. A 1971, 1263-1266.

66. Khazanova, N. E.; Sominskaya, E. E. Changes in the Volume of Ethane near Its Critical Point. Russ. J. Phys. Chem. (Engl. Transl.) 1971, 45, 88-89.

67. Lenoir, J. M.; Rebert, C. J.; Hipkin, H. G. Enthalpy of cis-2-Pentene and a Mixture with n-Pentane. J. Chem. Eng. Data 1971, 16, 401-404.

68. Miniovich, V. M.; Sorina, G. A. P-V-T Relations for Ethane in the Vicinity of Its Critical Point of Ethane. Russ. J. Phys. Chem. (Engl. Transl.) 1971, 45, 306-307.

69. Efremova, G. D.; Shvarts, A. V. Higher-order Critical Phenomena in Ternary Systems. The Methanol-Carbon Dioxide-Ethane System. Russ. J. Phys. Chem. (Engl. Transl.) 1972, 46, 237-239.

70. Efremova, G. D.; Sokolova, E. S. Boundary Curve and Critical Parameters of Propionic Acid. Russ. J. Phys. Chem. (Engl. Transl.) 1972, 46, 1084-1084.

71. Mousa, A. H. N.; Kay, W. B.; Kreglewski, A. The Critical Constants of Binary Mixtures of Certain Perfluoro-Compounds with Alkanes. J. Chem. Thermodyn. 1972, 4, 301-311.

72. Ogrin, T.; Zemva, B.; Bohinc, M.; Slivnik, J. Critical Constants and Liquid Densities of Xenon Difluoride and Xenon Tetrafluoride. J. Chem. Eng. Data 1972, 17, 418-419.

73. Pak, S. C.; Kay, W. B. The Critical Properties of Binary Hydrocarbon Systems. Ind. Eng. Chem. Fundam. 1972, 11, 255-267.

74. Tashmukhamedov, F. Determination of Critical Temperatures from Ultrasonic Data in Azeotropic HexaneEthanol Mixtures. Sov. Phys. - Acoust. (Engl. Transl.) 1972, 17, 527-528.

75. Dawson, P. P.; Silberberg, I. H.; McKetta, J. J. Volumetric Behavior, Vapor Pressures, and Critical Properties of Neopentane. J. Chem. Eng. Data 1973, 18, 7-15.

76. Douslin, D. R.; Harrison, R. H. Pressure, Volume, Temperature Relations of Ethane. J. Chem. Thermodyn. 1973, 5, 491-512.

77. Artyukhovskaya, L. M.; Shimanskaya, E. T.; Shimanskii, Yu. I. Behavior of the Refractive Index and Refraction of Heptane in a Wide Temperature Range along the Saturation Curve Including the Neighborhood of the Critical Point. Opt. Spektrosk. 1974, 37, 533-536. 
78. Burton, M.; Balzarini, D. Lorentz-Lorentz Coefficient of Ethane. Can. J. Phys. 1974, 52, 2011-2013.

79. Kay, W. B.; Young, C. L. Int. DATA Ser. Sel. Data Mixtures, Ser. A, 1974, 2, 156-157.

80. Kay, W. B.; Young, C. L. Int. DATA Ser. Sel. Data Mixtures, Ser. A, 1974, 2, 158-159.

81. Kay, W. B.; Young, C. L. Int. DATA Ser. Sel. Data Mixtures, Ser. A, 1974, 3, 194-195.

82. Kay, W. B.; Young, C. L. Int. DATA Ser. Sel. Data Mixtures, Ser. A, 1974, 3, 196-197.

83. Marshall, W. L.; Jones, E. V. Liquid-Vapor Critical Temperatures of Several Aqueous-Organic and OrganicOrganic Solution Systems. J. Inorg. Nucl. Chem. 1974, 36, 2319-2323.

84. Moldover, M. R. Visual Observation at the Critical Temperature and Density. J. Chem. Phys. 1974, 61, 17661778.

85. Strumpf, H. J.; Collings, A. F.; Pings, C. J. Viscosity of Xenon and Ethane in the Critical Region. J. Chem. Phys. 1974, 60, 3109-3123.

86. Kay, W. B.; Young, C. L. Int. DATA Ser. Sel. Data Mixtures, Ser. A, 1975, 1, 56-57.

87. Aftienjew, J.; Zawisza, A. High-Pressure Liquid-Vapour Equilibria, Critical State, and p(V,T,x) up to 503.15 $\mathrm{K}$ and 4.560 MPa for n-Pentane + n-Perfluoropentane. J. Chem. Thermodyn. 1977, 9, 153-165.

88. Bougard, J.; Jadot, R. Isothermal Vapor-Liquid Equilibria for the System 1,2-Dichloropropane - Propanal. $J$. Chem. Eng. Data 1977, 22, 88-90.

89. Mousa, A. H. N. The Physical Properties of Highly Purified Samples of Propane and n-Hexane. J. Chem. Thermodyn. 1977, 9, 1063-1065.

90. Mastroianni, M. J.; Stahl, R. F.; Sheldon, P. N. Physical and Thermodynamic Property of 1,1,2Trrifluorotrichloromethane (R-113). J. Chem. Eng. Data 1978, 23, 113-118.

91. Mousa, A. H. N. Study of Vapor Pressure and Critical Properties of Perfluoro-n-Hexane. J. Chem. Eng. Data 1978, 23, 133-134.

92. Saikawa, K.; Kijima, J.; Uematsu, M.; Watanabe, K. Determination of the Critical Temperature and Density of Hexafluoroethane. J. Chem. Eng. Data 1979, 24, 165-167.

93. Genco, J. M.; Teja, A. S.; Kay, W. B. Study of the Critical and Azeotropic Behavior of Binary Mixtures I Critical States of Perfluoromethylcyclohexane + Isomeric Hexane Systems. J. Chem. Eng. Data 1980, 25, 350 .

94. Morrison, G. Effect of Water on the Critical Points of Carbon Dioxide and Ethane. J. Phys. Chem. 1981, 85, 759-761.

95. Mousa, A. H. N. Critical Constants, Vapor Pressure, and Saturated Volumes of Hexafluoroacetylacetone. J. Chem. Eng. Data 1981, 26, 248-249.

96. Barber, J. R.; Kay, W. B.; Teja, A. S. A Study of the Volumetric and Phase Behavior of Binary System. AIChE J. 1982, 28, 134-138.

97. Mogollon, E.; Kay, W. B.; Teja, A. S. Modified Sealed-Tube Method for the Determination of Critical Temperature. Ind. Eng. Chem. Fundam. 1982, 21(2), 173-175.

98. Zawisza, A.; Vejrosta, J. High-Pressure Liquid-Vapor Equilibria, Critical State, and p(V, T, x) up to $573.15 \mathrm{~K}$ and 5.066 MPa for (Heptane + Propan-1-ol). J. Chem. Thermodyn. 1982, 14, 239-249.

99. Wolfe, D.; Kay, W. B.; Teja, A. S. Phase Equilibria in the n-Pentane + Pent-1-ene System 1. Critical States. J. Chem. Eng. Data 1983, 28, 319-322.

100. Higashi, Y.; Okazaki, S.; Takaishi, Y.; Uematsu, M.; Watanabe, K. Measurements of the Vapor-Liquid Coexistence Curve for the Binary R12 + R22 System in the Critical Region. J. Chem. Eng. Data 1984, 29, 31-36.

101. Morrison, G.; Kincaid, J. M. Critical Point Measurements on Nearly Polydisperse Fluids. AIChE J. 1984, 30, 257-262.

102. Wilson, K. S.; Lindley, D. D.; Kay, W. B.; Hershey, H. C. Virial Coefficients of Ethanol from 373.07 to 473.15 K. J. Chem. Eng. Data 1984, 29, 243-245.

103. Brunner, E. Fluid Mixtures at High Pressures II. Phase Separation and Critical Phenomena of (Ethane + an N-Alkanol) and of (Ethene + Methanol) and (Propane + Methanol). J. Chem. Thermodyn. 1985, 17, 871-885.

104. Garcia-Sanchez, F.; Trejo Rodriguez, A. Vapour Pressure and Critical Constants of 1, 2-Dichloroethane. J. Chem. Thermodyn. 1985, 17, 981-983. 
105. Mandlekar, A. V.; Kay, W. B.; Smith, R. L.; Teja, A. S. Phase Equilibria in The n-Hexane + Diethylamine System. Fluid Phase Equilib. 1985, 23, 79-88.

106. Matzik, I.; Schneider, G. M. Fluid Phase Equilibria of Binary Mixtures of Sulfur Hexafluoride with Octane, Nonane, Hendecane, and cis-Decahydronaphthalene at Temperature Between $280 \mathrm{~K}$ and $440 \mathrm{~K}$ and at Pressures Up to 140 Mpa. Ber. Bunsen-Ges. Phys. Chem. 1985, 89, 551.

107. Zawisza, A. High-Pressure Liquid-Vapour Equilibria, Critical State, and $\mathrm{p}(\mathrm{Vm}, \mathrm{T}, \mathrm{x})$ to $448.15 \mathrm{~K}$ and 4.053 MPa for $\{\mathrm{xC6H} 14+(1-\mathrm{x}) \mathrm{CH} 3 \mathrm{OH}\}$. J. Chem. Thermodyn. 1985, 17, 941-947.

108. Smith, R. L.; Anselme, M. J.; Teja, A. S. The Critical Temperatures of Isomeric Pentanols and Heptanols. Fluid Phase Equilib. 1986, 31, 161-170.

109. Smith, R. L.; Anselme, M.; Teja, A. S. The Measurement of Critical Properties of Thermally-Labile Substances. World Congress III of Chem. Eng. Tokyo. 1986, Vol. II, 135-139.

110. Brunner, E. Fluid Mixtures at High Pressures VI. Phase Separation and Critical Phenomena in 18 Binary Mixtures Containing Either Pyridine or Ethanoic Acid. J. Chem. Thermodyn. 1987, 19, 823-835.

111. Castillo-Lopez, N.; Trejo Rodriguez, A. The Critical Temperatures and Pressures of Several n-Alkanenitriles. J. Chem. Thermodyn. 1987, 19, 671-672.

112. Daubert, T. E.; Jalowka, J. W.; Goren, V. Vapor Pressure of 22 Pure Industrial Chemicals. AIChE Symp. Ser. 1987, 83(256), 128-156.

113. Ogrin, T.; Jesih, A.; Zemva, B. Critical Constants of Xenon Hexafluoride. J. Chem. Eng. Data 1987, 32, 401.

114. Abara, J. A.; Jennings, D. W.; Kay, W. B.; Teja, A. S. Phase Behavior in the Critical Region of Six Binary Mixtures of 2-Methylalkanes. J. Chem. Eng. Data 1988, 33, 242-247.

115. Anselme, M. J.; Teja, A. S. Critical Temperatures and Densities of Isomeric Alkanols with Six to Ten Carbon Atoms. Fluid Phase Equilib. 1988, 40, 127-134.

116. Brunner, E. Fluid Mixtures at High Pressures VI. Phase Separation and Critical Phenomena in 18 (n-Alkane + Ammonia) and 4 (n-Alkane + Methanol) Mixtures. J. Chem. Thermodyn. 1988, 20, $273-297$.

117. Li, L.; Kiran, E. Gas-Liquid Critical Properties of Methylamine + Nitrous Oxide and Methylamine + Ethylene Binary Mixtures. J. Chem. Eng. Data 1988, 33, 342-344.

118. Jangkamolkulchai, A.; Luks, K. D. Partial Miscibility Behavior of the Methane + Ethane + n-Docosane and the Methane + Ethane + n-Tetradecylbenzene Ternary Mixtures. J. Chem. Eng. Data 1989, 34, 92-99.

119. Rosenthal, D. J.; Teja, A. S. The Critical Properties of n-Alkanes Using a Low-Residence Time Flow Apparatus. AIChE J. 1989, 35, 1829-1834.

120. Teja, A. S.; Gude, M.; Rosenthal, D. J. Novel Methods for the Measurement of the Critical Properties of Thermally Unstable Fluids. Fluid Phase Equilib. 1989, 52, 193-200.

121. Weber, L. A. Simple Apparatus for Vapor-Liquid Equilibrium Measurements with Data for the Binary Systems of Carbon Dioxide with n-Butane and Isobutane. J. Chem. Eng. Data 1989, 34, 171-175.

122. Anselme, M. J.; Gude, M.; Teja, A. S. The Critical Temperatures and Densities of the n-Alkanes from Pentane to Octadecane. Fluid Phase Equilib. 1990, 57, 317-326.

123. Anselme, M. J.; Teja, A. S. The Critical Properties of Rapidly Reacting Substances. AIChE Symp. Ser. 1990, 86(279), 128-132.

124. Tanikawa, S.; Kabata, Y.; Sato, H.; Watanabe, K. Measurements of the Critical Parameters and the VaporLiquid Coexistence Curve in the Critical Region of HCFC-123. J. Chem. Eng. Data 1990, 35, 381-385.

125. Teja, A. S.; Anselme, M. J. The Critical Properties of Thermally Stable and Unstable Fluids. I. 1985 Results. AIChE Symp. Ser. 1990, 86(279), 115-121.

126. Teja, A. S.; Anselme, M. J. The Critical Properties of Thermally Stable and Unstable Fluids. II. 1986 Results. AIChE Symp. Ser. 1990, 86(279), 122-127.

127. Quadri, S. K.; Khilar, K. C.; Kudchadker, A. P.; Patni, M. J. Measurement of the Critical Temperatures and Critical Pressures of Some Thermally Stable or Mildly Unstable Alkanols. J. Chem. Thermodyn. 1991, 23, 67-76.

128. Steele, W. V.; Chirico, R. D.; Nguyen, A.; Hossenlopp, I. A.; Smith, N. K. DIPPR Project 8. DIPPR Data Ser. 1 1991, 101-134.

129. Teja, A. S.; Rosenthal, D. J. The Critical Pressures and Temperatures of Ten Substances Using a Low Residence Time Flow Apparatus. Experimental Results for Phase Equilibria and Pure Component Properties DIPPR DATA Series No. 1 1991, 96-100. 
130. Colgate, S. O.; Sivaraman, A.; Dejsupa, C. Sonic Speed and Critical Point Measurements in Ethane by the Acoustic Resonance Method. Fluid Phase Equilib. 1992, 76, 175-185.

131. Leu, A. D.; Robinson, D. B. High-Pressure Vapor-Liquid Equilibrium Phase Properties of the Octafluoropropane (K-218)-Chlorodifluoromethane (Freon-22) Binary System. J. Chem. Eng. Data 1992, 37, $7-10$.

132. Noles, J. R.; Zollweg, J. A. Vapor-Liquid Equilibrium for Chlorodifluoromethane + Dimethyl Ether from 283 to $395 \mathrm{~K}$ at Pressures to 5.0 MPa. J. Chem. Eng. Data 1992, 37, 306-310.

133. Salvi-Narkhede, M.; Wang, B. -H.; Adcock, J. I.; Van Hook, W. A. Vapor Pressures, Liquid Molar Volumes, Vapor Non-Ideality, and Critical Properties of Some Partially Fluorinated Ethers $\left(\mathrm{CF}_{3} \mathrm{OCF}_{2} \mathrm{CF}_{2} \mathrm{H}\right.$, $\mathrm{CF}_{3} \mathrm{OCF}_{2} \mathrm{H}$, and $\left.\mathrm{CF}_{3} \mathrm{OCH}_{3}\right)$, Some Perfluoroethers $\left(\mathrm{CF}_{3} \mathrm{OCF}_{2} \mathrm{OCF}_{3}, \mathrm{c}_{-} \mathrm{CF}_{2} \mathrm{OCF}_{2}\right.$, and $\left.c-\mathrm{CF}_{2} \mathrm{CF}_{2} \mathrm{CF}_{2} \mathrm{O}\right)$, and of $\mathrm{CHF}_{2} \mathrm{Br}$ and $\mathrm{CF}_{3} \mathrm{CFHCF}_{3}$. J. Chem. Thermodyn. 1992, 24, 1065-1075.

134. Tanikawa, S.; Tatoh, J.; Maezawa, Y.; Sato, H.; Watanabe, K. Vapor-Liquid Coexistence Curve and the Critical Parameters of 1-Chloro-1,1- Difluoroethane (HCFC-142b). J. Chem. Eng. Data 1992, 37, 74-76.

135. Chirico, R. D.; Knipmeyer, S. E.; Nguyen, A.; Steele, W. V. The Thermodynamic Properties to the Temperature $700 \mathrm{~K}$ of Naphthalene and of 2, 7-Dimethylnaphthalene. J. Chem. Thermodyn. 1993, 25, 14611494.

136. Nikitin, E. D.; Pavlov, P. A.; Skripov, P. V. Measurement of the Critical Properties of Thermally Unstable Substances and Mixtures by the Pulse-Heating Method. J. Chem. Thermodyn. 1993, 25, 869-880.

137. Salvi-Narkhede, M.; Adcock, J. L.; Gakh, A.; Van Hook, W. A. Vapor Pressures, Liquid Molar Volumes, Vapor Nonideality, and Critical Properties of Perfluoro-2-Oxapentane, Perfluorocyclooxapentane, Perfluoro2 ,4-Dioxapentane, And 1,1,1,3,3,4,4-Heptafluoro-2-Oxa. J. Chem. Thermodyn. 1993, 25, 643-647.

138. Tatoh, J.; Kuwabara, S.; Sato, H.; Watanabe, K. Measurements of the Vapor-Liquid Coexistence Curve in the Critical Region and the Critical Parameters of 1, 1, 2, 2-Tetrafluoroethane. J. Chem. Eng. Data 1993, 38, 116118.

139. Gude, M. T.; Teja, A. S. Measurement Techniques for Critical Properties of Unstable Substances. AIChE Symp. Ser. 1994, 90(298), 14-22.

140. Nikitin, E. D.; Pavlov, P. A.; Bessonova, N. V. Critical Constants of n-Alkanes with from 17 to 24 Carbon Atoms. J. Chem. Thermodyn. 1994, 26, 177-182.

141. Quadri, S. K.; Kudchadker, A. P. The Critical Temperatures and Critical Pressures of Some Binaries of a Polar Substance + another Polar Substance (Pentan-1-o1 + Isomers Of Hexanol). AIChE Symp. Ser. 1994, 298, 1-13.

142. Steele, W. V.; Chirico, R. D.; Hossenlopp, I. A.; Knipmeyer, S. E.; Nguyen, A.; Smith, N. K. DIPPR project 871. Determination of Ideal-Gas Enthalpies of Formation for Key Compounds. The 1990 Project Results. Experimental Results for DIPPR 1990-91 Projects on Phase Equilibria and Pure Component Properties, DIPPR Data Ser. No. 2, 1994, 188-215.

143. Steele, W. V.; Chirico, R. D.; Knipmeyer, S. E.; Nguyen, A. DIPPR Project 8. Experimental Results for DIPPR 1990-91 Projects on Phase Equilibria and Pure Component Properties DIPPR Data Series No. 2, 1994, 154-173.

144. Kuwabara, S.; Aoyama, H.; Sato, H.; Watanabe, K. Vapor-Liquid Coexistence Curves in the Critical Region and the Critical Temperatures and Densities of Difluoromethane and Pentafluoroethane. J. Chem. Eng. Data 1995, 40, 112-116.

145. Nikitin, E. D.; Pavlov, P. A.; Popov, A. P. (Gas + Liquid) Critical Temperatures and Pressures of Polyethene Glycols for $\mathrm{HOCH}_{2} \mathrm{CH}_{2} \mathrm{OH}$ to $\mathrm{H}\left(\mathrm{OCH}_{2} \mathrm{CH}_{2}\right)_{\mathrm{v}=13.2} \mathrm{OH}$. J. Chem. Thermodyn. 1995, 27, 43-51.

146. Nikitin, E. D.; Pavlov, P. A.; Popov, A. P.; Nikitina, H. E. Critical Properties of Hydrogen Peroxide Determined from Direct Measurements. J. Chem. Thermodyn. 1995, 27, 945-952.

147. Pulliam, M. K.; Gude, M. T.; Teja, A. S. Critical Temperatures and Densities of n-Alkanones. J. Chem. Eng. Data 1995, 40, 455-458.

148. Steele, W. V.; Chirico, R. D.; Nguyen, A.; Knipmeyer, S. E. Vapor Pressures, High-Temperature Heat Capacities, Critical Properties, Derived Thermodynamic Functions, and Barriers to Methyl-Group Rotation, for the Six Dimethylpyridines. J. Chem. Thermodyn. 1995, 27, 311-334.

149. Wilson, L. C.; Wilding, W. V.; Wilson, H. L.; Wilson, G. M. Critical Point Measurements by a New Flow Method and a Traditional Static Method. J. Chem. Eng. Data 1995, 40, 765-768. 
150. Aoyama, H.; Kishizawa, G.; Sato, H.; Watanabe, K. Vapor-Liquid Coexistence Curves in the Critical Region and the Critical Temperatures and Densities of 1,1,1,2-Tetrafluoroethane (R-134a), 1,1,1- Trifluoroethane (R143a), and 1,1,1,2,3,3-Hexafluoropropane (R-236ea). J. Chem. Eng. Data 1996, 41, 1046-1051.

151. Chirico, R. D.; Steele, W. V.; Nguyen, A.; Klots, T. D.; Knipmeyer, S. E. Thermodynamic Properties of Pyridine. I. Vapor Pressures, High-Temperature Heat Capacities, Densities, Critical Properties, Derived Thermodynamic Functions, Vibrational Assignment, and Derivation of Recommended Values. J. Chem. Thermodyn. 1996, 28, 797-818.

152. Sako, T.; Sato, M.; Nakazawa, N.; Oowa, M.; Yasumoto, M.; Ito, H.; Yamashita, S. Critical Properties of Fluorinated Ethers. J. Chem. Eng. Data 1996, 41, 802-805.

153. Steele, W. V.; Chirico, R. D.; Knipmeyer, S. E.; Nguyen, A. Vapor Pressure of Acetophenone, (+-)-1,2Butanediol, (+-)-1,3-Butanediol, Diethylene Glycol Monopropyl Ether, 1,3-Dimethyladamantane, 2Ethoxyethyl Acetate, Ethyl Octyl Sufide, and Pentyl Acetate. J. Chem. Eng. Data 1996, 41, 1255-1268.

154. Steele, W. V.; Chirico, R. D.; Knipmeyer, S. E.; Nguyen, A.; Smith, N. K. Thermodynamic Properties and Ideal-Gas Enthalpies of Formation for Butyl Vinyl Ether, 1,2-Dimethoxyethane, Methyl Glycolate, Bicyclo[2.2.1]hept-2-ene, 5-Vinylbicyclo[2.2.1] hept-2-ene, trans-Azobenzene. J. Chem. Eng. Data 1996, 41, 1285-1302.

155. Steele, W. V.; Chirico, R. D.; Knipmeyer, S. E.; Nguyen, A.; Smith, N. K.; Tasker, I. R. Thermodynamic Properties and Ideal-Gas Enthalpies of Formation for Cyclohexene, Phthalan (2,5-Dihydrobenzo-3,4-furan), Isoxazole, Octylamine, Dioctylamine, Trioctylamine, Phenyl Isocyanate, and 1,4,5,6-Tetrahydropyrimidine. J. Chem. Eng. Data 1996, 41, 1269-1284.

156. Suehiro, Y.; Nakajima, M.; Yamada, K.; Uematsu, M. Critical Parameters of $\left\{x \mathrm{CO}_{2}+(1-x) \mathrm{CHF}_{3}\right\}$ for $x=$ (1.0000, 0.7496, 0.5013, and 0.2522). J. Chem. Thermodyn. 1996, 28, 1153-1164.

157. Wilson, L. C.; Wilson, H. L.; Wilding, W. V.; Wilson, G. M. Critical Point Measurements for Fourteen Compounds by a Static Method and a Flow Method. J. Chem. Eng. Data 1996, 41, 1252-1254.

158. Chirico, R. D.; Knipmeyer, S. E.; Nguyen, A.; Reynolds, J. W.; Steele, W. V. Thermodynamic Equilibria in Xylene Isomerization. 2. The Thermodynamic Properties of m-Xylene. J. Chem. Eng. Data 1997, 42, 475487.

159. Chirico, R. D.; Knipmeyer, S. E.; Nguyen, A.; Cowell, A. B.; Reynolds, J. W.; Steele, W. V. Thermodynamic Equilibria in Xylene Isomerization. 3. The Thermodynamic Properties of o-Xylene. J. Chem. Eng. Data 1997, 42, 758-771.

160. Chirico, R. D.; Knipmeyer, S. E.; Nguyen, A.; Steele, W. V. Theromodynamic Equilibria in Xylene Isomerization. 1. The Thermodynamic Properties of p-Xylene. J. Chem. Eng. 1997, 42, 248-261.

161. Chirico, R. D.; Knipmeyer, S. E.; Nguyen, A.; Steele, W. V. Thermodynamic Equilibria in Xylene Isomerization. 4. The Thermodynamic Properties of Ethylbenzene. J. Chem. Eng. Data 1997, 42, 772-783.

162. Defibaugh, D. R.; Carrillo-Nava, E.; Hurly, J. J.; Moldover, M. R.; Schmidt, J. W.; Weber, L. A. Thermodynamic Properties of HFC-338mccq, $\mathrm{CF}_{3} \mathrm{CF}_{2} \mathrm{CF}_{2} \mathrm{CH}_{2} \mathrm{~F}, 1,1,1,2,2,3,3,4$-Octafluorobutane. J. Chem. Eng. Data 1997, 42, 488-496.

163. Duarte-Garza, H. A.; Hwang, C.-A.; Kellerman, S. A.; Miller, R. C.; Hall, K. R.; Holste, J. C.; Marsh, K. N.; Gammon, B. E. Vapor Pressure, Vapor Density, and Liquid Density for 1,1-Dichloro-1- Fluoroethane(R141b). J. Chem. Eng. Data 1997, 42, 497-501.

164. Duarte-Garza, H. A.; Stouffer, C. E.; Hall, K. R.; Holste, J. C.; Marsh, K. N.; Gammon, B. E. Experimental Critical Constants, Vapor Pressure and Vapor and Liquid Densities for Pentafluoroethane (R-125). J. Chem. Eng. Data 1997, 42, 745-753.

165. Gude, M. T.; Mendez-Santiago, J.; Teja, A. S. Critical Properties of Alkanoic Acids Using the Sealed Ampule Method. J. Chem. Eng. Data 1997, 42, 278-280.

166. Rosenthal, D. J.; Gude, M. T.; Teja, A. S.; Mendez-Santiago, J. The Critical Properties of Alkanoic Acids using a Low Residence Time Flow Method. Fluid Phase Equilib. 1997, 135, 89-95.

167. Steele, W. V.; Chirico, R. D.; Knipmeyer, S. E.; Nguyen, A. Vapor Pressure, Heat Capacity, and Density along the Saturation Line, Measurements for Cyclohexanol, 2-Cyclohexen-1-one, 1,2-Dichloropropane, 1,4Di-tert-butylbenzene, (.+-.)-2-Ethylhexanoic Acid, 2-(Methylamino)ethanol, Perfluoro- $n$-heptane, and Sulfolane. J. Chem. Eng. Data 1997, 42, 1021-1036.

168. Fujiwara, K.; Nakamura, S.; Noguchi, M. Critical Parameters and Vapor Pressure Measurements for 1, 1, 1Trifluoroethane (R-143a). J. Chem. Eng. Data 1998, 43, 55-59. 
169. Duan, Y. -Y.; Shi, L.; Zhu, M. -S.; Han, L. -Z. Critical Parameters and Saturated Density of Trifluoroiodomethane (CF3I). J. Chem. Eng. Data 1999, 44, 501-504.

170. Morton, D. W.; Lui, M.; Young, C. L. The (Gas + Liquid) Critical Temperature of Some Ethers, Esters, and Ketones. J. Chem. Thermo. 1999, 31, 675-684.

171. Morton, D. W.; Lui, M. P. W.; Tran, C. A.; Young, C. L. The Gas-Liquid Critical Temperature of Some Chlorinated Alkanes and Halogenated Aromatic Hydrocarbons. J. Chem. Eng. Data 2000, 45, 437-439.

172. Singh, H.; Lucien, F. P.; Foster, N. R. Critical Properties for Binary Mixtures of Ethane Containing Low Concentrates of n-Alkane. J. Chem. Eng. Data 2000, 45, 131-135.

173. VonNiederhausern, D. M.; Wilson, G. M.; Giles, N. F. Critical Point and Vapor Pressure Measurements at High Temperatures by Means of a New Apparatus with Ultralow Residence Times. J. Chem. Eng. Data 2000, 45, 157-160.

174. VonNiederhausern, D. M.; Wilson, L. C.; Giles, N. F. Critical-Point Measurement for Nine Compounds by a Flow Method. J. Chem. Eng. Data 2000, 45, 154-156.

175. Liu, T.; Fu, J.; Wang, K.; Gao, Y.; Yuan, W. Gas-Liquid Critical Properties of Ethylene + Benzene. J. Chem. Eng. Data 2001, 46, 809-812.

176. Polikhronidi, N. G.; Abdulagatov, I. M.; Magee, J. W.; Batyrova, R. G. Isochoric Heat Capacity for Toluene Near Phase Transitions and the Critical Point. J. Chem. Eng. Data 2001, 46, 1064-1071.

177. Sako, T.; Yasumoto, M.; Nakazawa, N.; Kamizawa, C. Critical Parameters and Normal Boiling Temperatures of Five Fluorinated Ethers and Two Fluorinated Ketones. J. Chem. Eng. Data 2001, 46, 1078-1081.

178. Nikitin, E. D.; Popov, A. P.; Bogatishcheva, N. S.; Yatluk, Y. G. Vapor-Liquid Critical Properties of nAlkylbenzenes from Toluene to 1-Phenyltridecane. J. Chem. Eng. Data 2002, 47, 1012-1016.

179. Steele, W. V.; Chirico, R. D.; Cowell, A. B.; Knipmeyer, S. E.; Nguyen, A. Thermodynamic Properties and Ideal-Gas Enthalpies of Formation for Methyl Benzoate, Ethyl Benzoate, (R)-(+)-Limonene, tert-Amyl Methyl Ether, trans-Crotonaldehyde, and Diethylene Glycol. J. Chem. Eng. Data 2002, 47, 667-688.

180. Steele, W. V.; Chirico, R. D.; Knipmeyer, S. E.; Nguyen, A. Vapor Pressure, Heat Capacity, and Density along the Saturation Line: Measurements for Benzenamine, Butylbenzene, sec-Butylbenzene, tertButylbenzene, 2,2-Dimethylbutanoic Acid, Tridecafluoroheptanoic Acid, 2-Butyl-2-ethyl-1,3-propanediol, 2,2,4-Trimethyl-1,3-pentanediol, and 1-Chloro-2-propanol. J. Chem. Eng. Data 2002, 47, 648-666.

181. Wilson, G. M.; VonNiederhausern, D. M.; Giles, N. F. Critical Point and Vapor Pressure Measurements for Nine Compounds by a Low Residence Time Flow Method. J. Chem. Eng. Data 2002, 47, 761-764.

182. Oh, B. C.; Lee, S.; Seo, J.; Kim, H. Isothermal Vapor-Liquid Equilibria for the 2-Propanol + n-Heptane System near the Critical Region. J. Chem. Eng. Data 2000, 49, 221-223.

183. Duan, Y. -Y.; Shi, L.; Sun, L. -Q.; Zhu, M. -S.; Han, L. -Z. Thermodynamic Properties of Trifluoroiodomethane $\left(\mathrm{CF}_{3} \mathrm{I}\right)$. Int. J. Thermophys. 2000, 21, 393-404.

184. Nikitin, E. D. Pavlov, P. A. Popov, A. P. Critical temperatures and pressures of some alkanoic acids (C2 to C22) using the pulse-heating. Fluid Phase Equilib. 2001, 189, 151-161.

185. Steele, W. V.; Chirico, R. D.; Cowell, A. B. Knipmeyer, S. E. Nguyen, A. Thermodynamic Properties and Ideal-Gas Enthalpies of Formation for trans-Methyl Cinnamate, -Methyl Cinnamaldehyde, Methyl Methacrylate, 1-Nonyne, Trimethylacetic Acid, Trimethylacetic Anhydride, and Ethyl Trimethyl Acetate. $J$. Chem. Eng. Data 2002, 47, 700-714.

186. Steele, W. V.; Chirico, R. D.; Cowell, A. B. Knipmeyer, S. E. Nguyen, A. Thermodynamic Properties and Ideal-Gas Enthalpies of Formation for 1,4-Diisopropylbenzene, 1,2,4,5-Tetraisopropylbenzene, Cyclohexanone Oxime, Dimethyl Malonate, Glutaric Acid, and Pimelic Acid. J. Chem. Eng. Data 2002, 47, 725-739.

187. Steele, W. V.; Chirico, R. D.; Knipmeyer, S. E. Nguyen, A. Measurements of Vapor Pressure, Heat Capacity, and Density along the Saturation Line for -Caprolactam, Pyrazine, 1,2-Propanediol, Triethylene Glycol, Phenyl Acetylene, and Diphenyl Acetylene. J. Chem. Eng. Data 2002, 47, 689-699.

188. Pitschmann, M. Straub, J. The Thermal Diffusivity of the Refrigerants R32, R125, and R143a. Int. J. Thermophys. 2002, 23, 877-904.

189. Yasumoto, M.; Yamada, Y.; Murata, J.; Urata, S.; Otake, K. Critical Parameters and Vapor Pressures Measurements of Hydrofluoroethers at High Temperatures. J. Chem. Eng. Data 2003, 48, 1368-1379. 
190. Otake, K.; Yasumoto, M.; Yamada, Y.; Murata, J.; Urata, S. Critical Parameters and Vapor Pressure Measurements of Potential Replacements for Chlorofluorocarbons-Four Hydrofluoroketones and a Hydrolfuoroamine. J. Chem. Eng. Data 2003, 48, 1380-1383.

191. Nikitin, E. D.; Popov, A. P.; Bogatishcheva, N. S. Critical Point Measurements for Five n-Alkylcyclohexanes (C6 to C10) by the Pulse-Heating Method. J. Chem. Eng. Data 2003, 48, 1137-1140.

192. Liu, J.; Qin, Z.; Wang, G.; Hou, X.; Wang, J. Critical Properties of Binary and Ternary Mixtures of Hexane + Methanol, Hexane + Carbon Dioxide, Methanol + Carbon Dioxide and Hexane + Carbon Dioxide + Methanol. J. Chem. Eng. Data 2003, 48, 1610-1613.

193. Oh, B. C.; Lee, S.; Seo, J.; Kim, H. Isothermal Vapor-Liquid Equilibria for the 2-Propanol + n-Heptane System near the Critical Region. J. Chem. Eng. Data 2004, 49, 221-223.

194. Morton, D. W.; Lui, M. P. W.; Tran, C. A.; Young, C. L. Gas-Liquid Critical Temperatures of Some Alkenes, Amines, and Cyclic Hydrocarbons. J. Chem. Eng. Data 2004, 49, 283-285. 